\title{
LETTERS
}

\section{Safety and efficacy of TNF $\alpha$ blockade in relapsing vasculitis}

\author{
A D Booth, H J Jefferson, W Ayliffe, P A Andrews, D R Jayne
}

Ann Rheum Dis 2002;61:559

B lockade of tumour necrosis factor alpha (TNF $\alpha)$ using infliximab, a chimeric monoclonal antibody against $\mathrm{TNF} \alpha$, is an effective treatment in rheumatoid arthritis and Crohn's disease. ${ }^{12}$ Sifikakis reported success using infliximab in sight threatening Behçet's disease. ${ }^{3}$ A preliminary study has also reported clinical improvements in the primary systemic vasculitis, Wegener's granulomatosis, with the soluble TNF $\alpha$ receptor etanercept. ${ }^{4}$ The benefit of lenercept, a soluble p 55 TNF $\alpha$ receptor fusion protein, on digital vasculitis in rheumatoid arthritis has also been reported. ${ }^{5}$

We report the compassionate treatment of six patients with refractory vasculitis using infliximab. Diagnoses were Wegener's granulomatosis in three and microscopic polyangiitis in three. Three patients were positive for proteinase-3 antineutrophil cytoplasmic antibodies (PR3-ANCA) and one for myeloperoxidase (MPO)-ANCA. Four were female, with a mean age of 58 years (range 23-77) and mean disease duration of 3.5 years. All had had at least three clinical relapses and had received prolonged treatment with corticosteroids and at least four immunosuppressive drugs. At the time of infliximab treatment the eyes were affected in four patients and the lung in three; in addition, five had profound constitutional symptoms. The mean prednisolone dose was $17 \mathrm{mg}$.

Three intravenous doses of infliximab $200 \mathrm{mg}$ were given at monthly intervals for three months. One patient complained of fatigue, myalgia, and blurred vision 24 hours after the first infusion, which did not recur on rechallenge. Infliximab was otherwise well tolerated. Five patients had remission of their disease, four within two weeks of treatment. This allowed steroid withdrawal in three and reduction by more than $50 \%$ in two. Disease activity assessed by the Birmingham Vasculitis Activity Scores (BVAS) improved from a mean of 6.3 to 0.8 at three months (fig 1). ${ }^{6}$ One patient receiving continued infliximab for six months relapsed when the treatment interval was extended to two months. Mean falls in erythrocyte sedimentation rate and $\mathrm{C}$ reactive protein were $17 \mathrm{~mm} / \mathrm{lst} \mathrm{h}$ and 13 $\mathrm{mg} / \mathrm{l}$, respectively. The ANCA status was unchanged.

Anti-TNF $\alpha$ treatment heralds a new wave of specifically targeted biological interventions of potential value in the treatment of vasculitis. It offers the hope of improved therapeutic efficacy over current agents and the possibility of reducing exposure to steroids and immunosuppressive drugs. Further studies are warranted to confirm these observations and explore the role of infliximab as a component of initial protocols.

Authors' affiliations

A D Booth, D R Jayne, Department of Medicine, Addenbrooke's Hospital, Cambridge CB2 2QQ, UK

H J Jefferson, P A Andrews, SW Thames Renal and Transplantation Unit, St Helier Hospital, Carshalton SMI AA, UK

W Ayliffe, Mayday University Teaching Hospital, Croydon CR7 7YE, UK

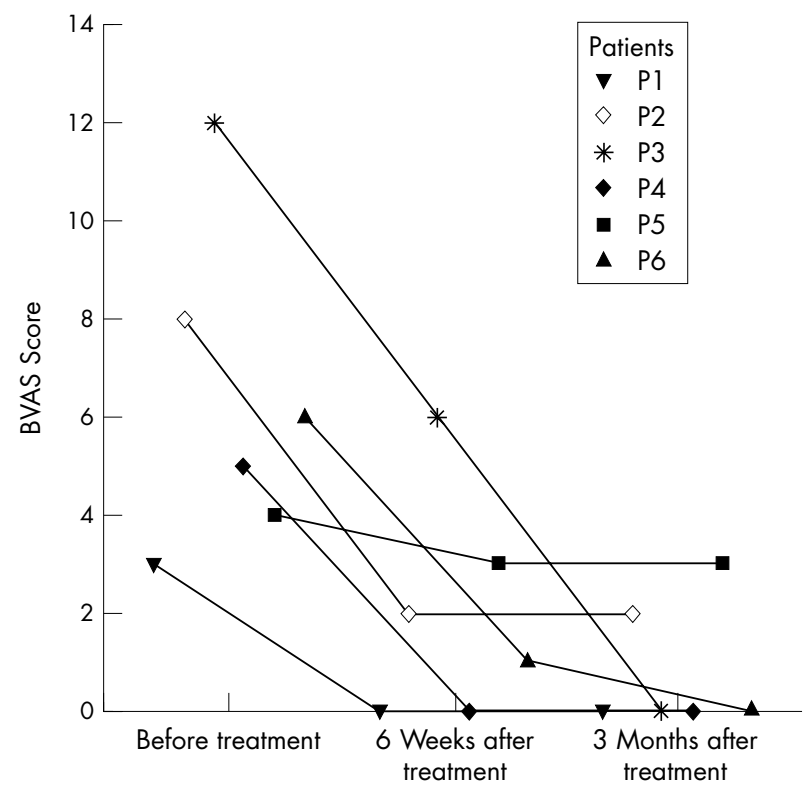

Figure 1 BVAS scores for the six patients treated with infliximab.

Correspondence to: Dr A D Booth, Department of Renal Medicine, Box No 118 , Addenbrooke's NHS Trust, Hills Road, Cambridge CB2 2QQ, UK; tonybooth $1 @$ yahoo.co.uk

Accepted 25 February 2002

\section{REFERENCES}

1 Maini R, St Clair EW, Breedveld F, Furst D, Kalden J, Weisman M, et al Infliximab (chimeric anti-tumour necrosis factor alpha monoclonal antibody) versus placebo in rheumatoid arthritis patients receiving concomitant methotrexate: a randomised phase III trial. Lancet 1999;354:1932-9.

2 Present DH, Braakman T, DeWoody KL, Schaible TF, Rutgeerts PJ. A short-term study of chimeric monoclonal antibody $\mathrm{CA} 2$ to tumour necrosis factor alpha for Crohn's Disease cA2 Study Group. N Engl J Med 1997;337:1029-35.

3 Sifikakis PP, Theodossiadis PG, Katsiari CG, Kaklamanis P, Markomichelakis NN. Effect of infliximab on sight-theatening panuveitis in Behçet's disease. Lancet 2001;358:295-6.

4 Stone JH, Uhlfelder ML, Hellmann DB, Crook S, Bedocs NM, Hoffman GS. Etanercept combined with conventional treatment in Wegener's granulomatosis: a six-month open-label trial to evaluate safety. Arthritis Rheum 2001;44:1149-54.

5 Den Broeder AA, van den Hoogan FHJ, van de Putte LBA. Isolated digital vasculitis in a patient with rheumatoid arthritis: good response to tumour necrosis factor $\alpha$ blocking treatment. Ann Rheum Dis 2001;60:538-9.

6 Luqmani RA, Bacon PA, Moots RJ, Janssen BA, Pall A, Emery P, et al. Birmingham vasculitis activity score (BVAS) in systemic necrotizing vasculitis. Q J Med 1994;87:671-8 


\title{
Anti-tumour necrosis factor monoclonal antibody treatment for ocular Behçet's disease
}

\author{
G Triolo, M Vadalà, A Accardo-Palumbo, A Ferrante, F Ciccia, E Giardina, P Citarrella, \\ G Lodato, G Licata
}

Ann Rheum Dis 2002;61:560-561

O cular involvement is a common and serious component of Behçet's disease (BD). This manifestation worsens without treatment, and loss of vision occurs an average of 3.3 years after the onset of eye symptoms. ${ }^{1}$ High levels of tumour necrosis factor (TNF) $\alpha$ have been found in the serum of patients with BD together with other proinflammatory cytokines. ${ }^{23}$ Many studies indicate a strong polarised Thl immune response as in rheumatoid arthritis and Crohn's disease. ${ }^{4}$

High affinity monoclonal anti-TNF $\alpha$ antibody treatment has been recently introduced for patients with Crohn's disease or rheumatoid arthritis who were resistant to standard treatment. We describe the use of the anti-TNF $\alpha$ chimeric monoclonal antibody, infliximab (Remicade; Centocor Inc, Malvern, PA; Schering Plough SpA, Italy) in a patient with BD who exhibited a severe ocular involvement refractory to standard treatment.

\section{CASE REPORT}

An 18 year old man with BD was admitted in January 2001. He had been diagnosed with BD four years earlier in view of his presentation of recurrent oral and genital aphthous ulcers, polyarthritis, erythema nodosum, and superficial thrombophlebitis. The onset of the ocular disease was in 1999, when the patient was treated with steroids and cyclosporin for bilateral posterior uveitis. In the course of cyclosporin treatment he had several attacks of uveitis in both the eyes.
Cyclophosphamide was introduced without a satisfactory control of disease symptoms and of the ocular manifestations.

A new relapse of severe neuroretinitis occurred in October 2000. He was treated with intravenous methylprednisolone, followed by oral prednisone $(50 \mathrm{mg} /$ day), topical steroids, and mydriatic agents. Tapering of the prednisone dose resulted in November in a new acute attack of neuroretinitis in the left eye. Intravenous methylprednisolone was reintroduced, followed by $75 \mathrm{mg}$ of oral prednisone and by local peribulbar injection of methylprednisolone every 15 days. Recovery was slow and less evident and, the visual acuity being 20/30, optic disc oedema and retinal vasculitis were still present. The patient received prednisone maintenance treatment ( $15 \mathrm{mg}$ /day) for approximately four weeks before receiving an infliximab infusion.

At admission, fluorescein angiography (fig lA) showed a hyperfluorescent optic disc in both eyes, and diffuse irregular mottled retinal hyperfluorescence and haemorrhagic hypofluorescence in the left eye. Oral and genital ulcerations were present together with erythema nodosum, thrombophlebitis, and arthritis. An infusion protocol was designed and approved by the Department of Internal Medicine Institutional Board and informed consent for treatment was obtained from the patient.

The patients was infused with infliximab, $5 \mathrm{mg} / \mathrm{kg}$, by a two hour infusion, at weeks $0,2,4$, and 8 , and the patient observed for a further two hours without adverse effects. An improvement in symptoms was noticed within 24 hours after
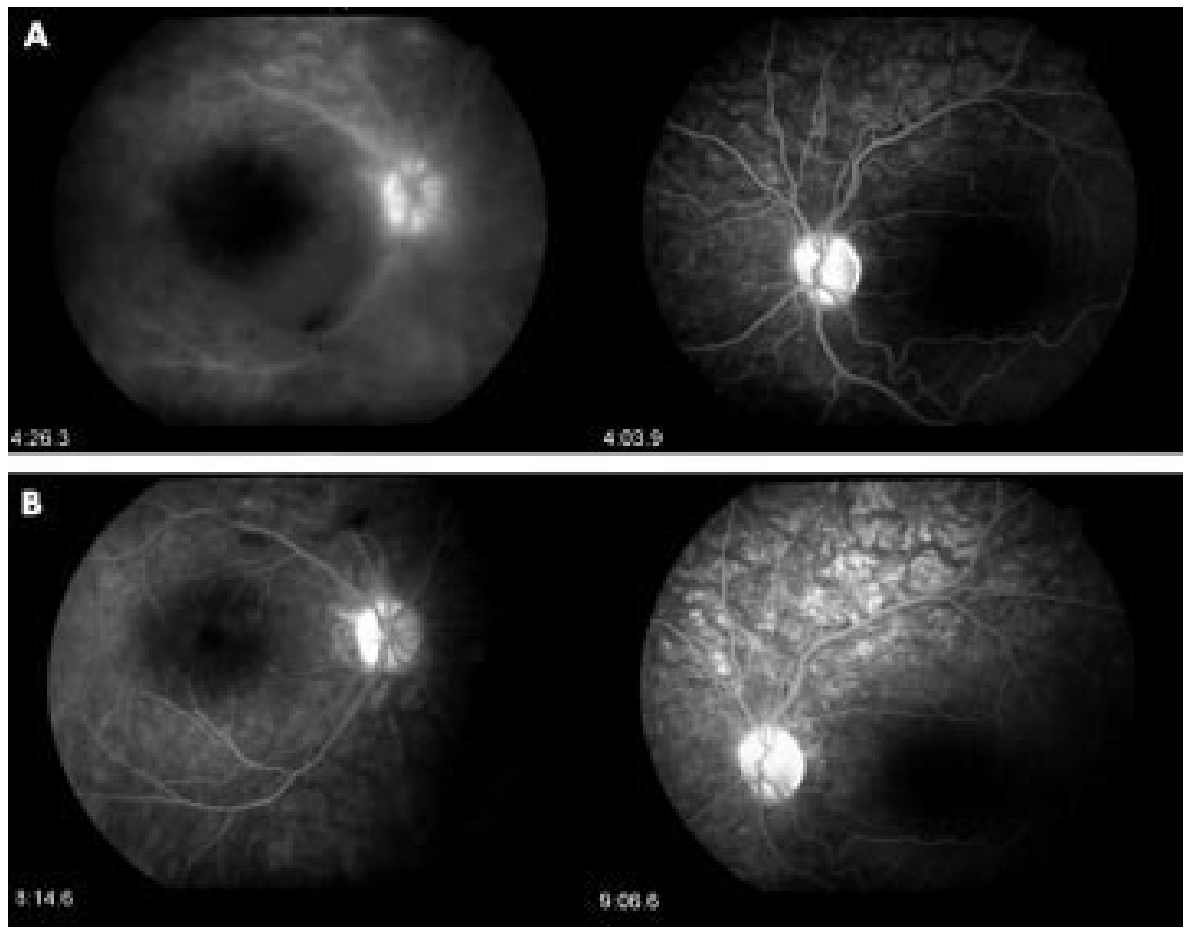

Figure 1 (A) Fluorescein angiography obtained at admission, showing a hyperfluorescent optic disc in both eyes, diffuse irregular mottled retinal hyperfluorescence, and haemorrhagic hypofluorescence in the left eye. (B) Fluorescein angiography obtained before the third infusion, showing a normal optic disc aspect, improvement of macular oedema in the right eye and still in the mottled aspect of retinal capillary filling. 
receiving the first infusion. At the time of the second infusion he had a complete remission of all signs and symptoms. A new fluorescein angiography was performed just before the third infusion. At that time there was a normal optic disc aspect, improvement of macular oedema in the right eye and still in the mottled aspect of retinal capillary filling (fig 1B). Before the first infusion the erythrocyte sedimentation rate was 35 $\mathrm{mm} / \mathrm{lst} \mathrm{h}$ and the $\mathrm{C}$ reactive protein level was $34 \mathrm{mg} / \mathrm{l}$. They decreased to $22 \mathrm{~mm} / \mathrm{lst} \mathrm{h}$ and $6 \mathrm{mg} / \mathrm{l}$ (normal $<10 \mathrm{mg} / \mathrm{l}$ ), respectively, by week 2 and remained within the normal range for the duration of the study.

\section{DISCUSSION}

This is the first report, to our knowledge, of the treatment of ocular BD with anticytokine specific treatment. Treatment with infliximab led, in our patient, to a complete remission of all disease manifestations and there was no recurrence after steroid tapering.

Three interesting points can be made. Firstly, the drug had a profound effect on ocular BD as well as on the other manifestations of disease. This effect on global diseases seems to be remarkable, as standard treatments had failed in our patient. Secondly, the onset of improvement was fast. Thirdly, when a loading dose regimen of four infusions (weeks $0,2,6$, and 8) was used, remission continued for up to eight weeks. Further confirmation of the beneficial effects of TNF $\alpha$ blockade in randomised, controlled, double blind studies is necessary.

\section{Authors' affiliations}

G Triolo, A Accardo-Palumbo, A Ferrante, F Ciccia, E Giardina,

Rheumatology and Clinical Immunology Unit, Palermo University

Hospital, Italy

M Vadalà, G Lodato, Division of Ophthalmology, Palermo University Hospital

P Citarrella, Division of Haematology, Palermo University Hospital

G Licata, Division of Internal Medicine, Palermo University Hospital

Correspondence to: Professor G Triolo, Rheumatology and Clinical Immunology Unit, Istituto di Clinica Medica, Policlinico Universitario, Piazza delle Cliniche 2, 90127 Palermo, Italy; triolog@tiscalinet.it

Accepted 7 November 2001

\section{REFERENCES}

1 Mamo JG. The rate of visual loss in Behçet's disease. Arch Ophthalmol 1970;84:451-2.

2 Amzaoui K, Hamza M, Ayed K. Production of TNF alpha and II-1 in active Behcet's disease. J Rheumatol 1990;17:1428-9.

3 Megel JL, Dilsen N, Sanguedolce V, Gul A, Bongrand P, Ocal L, et al. Overproduction of monocyte derived tumor necrosis factor alpha, interleukin (IL)6, IL-8 and increased neutophil superoxide generation in Behçet's disease. A comparative study with familial Mediterranean fever and healthy subjects. J Rheumatol 1993;20:1944-9.

4 Frassanito MA, Dammacco R, Cafforio P, Dammacco F. Th1 polarization of the immune response in Behçet's disease: a putative role of interleukin-12. Arthritis Rheum 1999;42:1967-74.

\section{Is hirudin a potential therapeutic agent for arthritis?}

\section{K Scott}

A recent pilot study by Michalsen et al showed that a single brief treatment with medicinal leeches (Hirudo medicinalis) can give relatively long term relief from pain in osteoarthritic joints. A number of leech salivary components are known, which may contribute to this effect. ${ }^{1}$ Although there was no evidence for any therapeutic outcomes, other than pain relief, the extended timescale suggests that one or more leech components may exert more than an anaesthetic or analgesic effect. Independent evidence indicates that the leech anticoagulant protein, hirudin, may make a significant contribution to this phenomenon.

A synovial stimulatory protein (SSP), acting as an autoantigen to which $\mathrm{T}$ lymphocytes from patients with rheumatoid arthritis respond, has been identified in synovial fluid. ${ }^{2}$ A smaller protein, derived from human fibroblasts, and identifiable from its amino acid sequence as a fragment of the SSP, has been found to bind to a hirudin-agarose affinity chromatography matrix. ${ }^{3}$ More recently, we have shown that both the SSP and its smaller derivative, now known as the DING protein, are found in synovial fluid samples and synovial fibroblasts from normal subjects, and from patients with a range of arthritic conditions, including rheumatoid and osteoarthritis. The proteins act as autocrine growth stimulators for normal and arthritic synovial fibroblasts. ${ }^{4}$ The presence of hirudin can inhibit this stimulation. ${ }^{3}$ Given that hyperproliferation of synovial fibroblasts is believed to contribute to the formation of the destructive pannus that is characteristic of some arthritic joints, ${ }^{5}$ the SSP and DING protein may act to promote this process, and hirudin may have the potential to retard it. Hirudin might thus have value in treating arthritis. Recombinant hirudin has already been used in a range of therapeutic anticoagulant applications, ${ }^{6-8}$ so patient safety and other clinical data have been collected and evaluated. A trial of hirudin in an antiarthritis role may now be appropriate.
The first DING protein isolates displayed proteolytic activity, and its inhibition was believed to be the basis of the action of hirudin, but subsequent DING preparations have had little or no proteolytic activity. ${ }^{3}$ The basis of the inhibitory action of hirudin is thus not known. Peptides derived from hirudin such as hirulog (bivalirudin), which are effective anticoagulants by virtue of thrombin inhibition, ${ }^{9}{ }^{10}$ may not possess the ability to bind and inhibit the SSP or DING proteins.

\section{ACKNOWLEDGEMENTS}

The experiments from the author's laboratory were supported by the Auckland Medical Research Foundation, and the Staff Research Fund of the University of Auckland.

\section{Author's affiliations}

K Scott, School of Biological Sciences, University of Auckland, Private Bag 92019, Auckland, New Zealand Correspondence to Dr Scott; k.scott@auckland.ac.nz

Accepted 18 December 2001

\section{REFERENCES}

1 Michalsen A, Deuse U, Esch T, Dobos G, Moebus S. Effect of leeches therapy (Hirudo medicinalis) in painful osteoarthritis of the knee: a pilot study. Ann Rheum Dis 2001;60:986

2 Hain NAK, Stuhlmuller B, Hahn GR, Kalden JR, Deutzmann R, Burmester GR. Biochemical characterisation and microsequencing of a $205 \mathrm{kDa}$ synovial protein stimulatory for $T$ cells and reactive with rheumatoid factor containing sera. J Immunol 1996; 157:1773-80.

3 Bush D, Fritz H, Knight C, Mount J, Scott K. A hirudin-sensitive, growth-related proteinase from human fibroblasts. Biol Chem 1998;379:225-9.

4 Adams L, Davey S, Scott K. The DING protein: an autocrine growth-stimulatory protein related to the human synovial stimulatory protein. Biochim Biophys Acta (in press). 
5 Mizel SB, Dayer JM, Krane SM, Mergenhagen SE. Stimulation of rheumatoid synovial cell collagenase and prostaglandin production by partially purified lymphocyte-activating factor. Proc Natl Acad Sci USA 1981;78:2474-7

6 Topol E, GUSTO llb investigators. A comparison of recombinant hirudin with heparin for the treatment of acute coronary syndromes. $N$ Engl J Med 1996;335:775-82

7 Reilly MP, Weiss R, Askenase A, Tuite C, Soulen M, Mohler ER. Hirudin therapy during thrombolysis for venous thrombosis in heparin-induced thrombocytopenia. Vasc Med 2000:5:239-42.
8 Saner F, Hertl M, Broelsch CE. Anticoagulation with hirudin for continuous veno-venous hemodialysis in liver transplantation. Acta Anaesthesiol Scand 2001;45:914-18.

9 Maraganore JM, Bourdon P, Jablonski J, Ramachandran KL, Fenton JW. Design and characterisation of hirulogs, a novel class of bivalent peptide inhibitors of thrombin. Biochemistry 1990;29:7095-101.

10 Kong DF, Topol EJ, Bittl JA, White HD, Theroux P, Hasselblad V, et al. Clinical outcomes of bivalirudin for ischemic heart disease. Circulation 1999; 100:2049-53.

\section{Steroid induced psychosis in systemic lupus erythematosus: a possible role of serum albumin level}

\section{F López-Medrano, R Cervera, O Trejo, J Font, M Ingelmo}

S teroids may have diverse and sometimes severe adverse effects in the short and long term. ${ }^{1}$ We present three patients with systemic lupus erythematosus (SLE) ${ }^{2}$ and steroid induced psychosis (table 1), emphasising the importance that serum albumin levels may have on the development of this complication.

\section{CASE REPORTS}

\section{Case 1}

Patient No 1 is a 20 year old woman with SLE diagnosed five years ago, in whom a serum albumin level of $24 \mathrm{~g} / \mathrm{l}$ and proteinuria of $3.2 \mathrm{~g} / \mathrm{l}$ were detected in routine tests. Diffuse proliferative lupus nephritis was diagnosed by renal biopsy and she was treated with one pulse of cyclophosphamide (500 $\mathrm{mg})$ and oral prednisone (60 mg/day). Three days later she developed anxiety, insomnia, euphoria, verbosity, grandiosity, and megalomaniac ideas. She was treated with oral risperidone $(2 \mathrm{mg} / 12 \mathrm{~h})$, oral clonazepam $(0.5 \mathrm{mg} / 12 \mathrm{~h})$, and the prednisone dosage was progressively tapered. Over the next 15 days she experienced a fluctuating but progressive improvement until she became psychiatrically asymptomatic. Five years previously, when she was first diagnosed as having SLE, she had been treated with oral prednisone $(60 \mathrm{mg} /$ day) but had not had any psychiatric symptoms. At that time, however, she had serum albumin levels of $33 \mathrm{~g} / \mathrm{l}$ without proteinuria.

\section{Case 2}

Patient No 2, a 21 year old woman who was diagnosed as having SLE, with cutaneous, articular and renal involvement, started treatment with oral prednisone $(30 \mathrm{mg} /$ day $)$. At that time she had a serum albumin level of $30.2 \mathrm{~g} / \mathrm{l}$ and proteinuria of $2.37 \mathrm{~g} /$ day. Renal biopsy was refused by the patient.
Over the following days and in a progressive manner, she developed mania, with euphoria, disinhibition as well as ideas of grandiosity. All these manifestations disappeared under psychiatric supervision and when steroids were discontinued.

\section{Case 3}

Patient No 3 is a 36 year old woman who had been diagnosed as having SLE with diffuse proliferative lupus nephritis seven years before. She had started oral prednisone $(60 \mathrm{mg} /$ day $)$, without adverse psychiatric effects. At that time, she had serum total protein level of $66 \mathrm{~g} / \mathrm{l}$ and a serum albumin level of $43 \mathrm{~g} / \mathrm{l}$. She currently presented with an articular "flare" of her lupus, and started treatment with oral prednisone (30 $\mathrm{mg} /$ day). Her total protein level was $59 \mathrm{~g} / \mathrm{l}$, the serum albumin level fell to $29 \mathrm{~g} / \mathrm{l}$ with proteinuria of $1.2 \mathrm{~g} / \mathrm{l}$. Seven days later, she developed anxiety, insomnia, and hyperactivity that disappeared over the following few days after reduction of the dose of prednisone to $2.5 \mathrm{mg} /$ day.

\section{DISCUSSION}

Steroid induced psychiatric disturbances appear in 3-6\% of the patients who are treated with these drugs..$^{3-6}$ The differential diagnosis with lupus psychosis ${ }^{7}$ is difficult. In case of doubt, some authors advocate increasing the dose of steroids and awaiting a clinical response over the next days. Others advocate rapid tapering and stopping steroids in order to eliminate a drug induced adverse event.

Our three patients developed psychiatric symptoms while receiving steroids for lupus nephritis with hypoalbuminaemia and significative proteinuria. Moreover, it seems relevant that

Table 1 Main clinical features of three patients with SLE and steroid induced psychosis

\begin{tabular}{llll}
\hline & Patient 1 & Patient 2 & Patient 3 \\
\hline Sex & Female & Female & Female \\
Age & 20 & 21 & 36 \\
Years after SLE diagnosis & 5 & Present diagnosis & 7 \\
Treatment at SLE diagnosis & Prednisone $60 \mathrm{mg} /$ day & See present diagnosis & Prednisone $60 \mathrm{mg} /$ day \\
Serum albumin at SLE diagnosis (g/l) & 33 & See present diagnosis & 43 \\
Psychiatric manifestations at SLE diagnosis & No & See present diagnosis & No \\
Present diagnosis & Lupus nephritis & Lupus nephritis & Articular and cutaneous flare \\
Serum albumin at present diagnosis (g/l) & 24 & 30 & 29 \\
Proteinuria at present diagnosis (g/day) & 3.2 & 2.37 & 1.2 \\
Treatment of present diagnosis & Prednisone $60 \mathrm{mg} /$ day & Prednisone 30 mg/day & Prednisone 30 mg/day \\
Psychiatric manifestations at present diagnosis & Yes & Yes & Yes \\
\hline
\end{tabular}


two of them (patients 1 and 3) had not developed psychiatric manifestations when they had previously been receiving similar doses of steroids, but had higher serum albumin levels at that time. Lewis et al found a 37\% incidence of adverse effects of steroids in those patients with serum albumin $<25 \mathrm{~g} / \mathrm{l}$ but of only $15 \%$ in those with higher serum albumin. ${ }^{8}$ The explanation for these findings may be that corticosteroid binding globulin does not bind to synthetic steroids, whose transport depends on serum albumin which, by contrast, presents low affinity but a great capacity to transport the steroids because of its high plasma concentration. Steroids are biologically inactive when bound to albumin. Therefore, the free (and active) fraction of steroids is higher in patients with low plasma albumin levels, and this will expose the patient to more adverse effects.

Interestingly, there is a lower incidence of psychosis in other groups of patients treated with steroids (for example, those with chronic obstructive pulmonary disease). ${ }^{9}$ Therefore, those patients whose disease causes low levels of serum proteins (as in those with SLE) will be more predisposed to have adverse effects of steroids.

Authors' affiliations

F López-Medrano, R Cervera, O Trejo, J Font, M Ingelmo, Department of Autoimmune Diseases, Institut Clínic d'Infeccions i Immunologia, Hospital Clínic, Institut d'Investigacions Biomèdiques August Pi i Sunyer (IDIBAPS), University of Barcelona, Barcelona, Catalonia, Spain
F López-Medrano is currently at Servicio de Medicina Interna, Hospital Universitario 12 de Octubre, Madrid, Spain

Correspondence to: Dr R Cervera, Servei de Malalties Autoimmunes, Hospital Clínic, Villarroel 170, 08036-Barcelona, Catalonia, Spain; rcervera@clinic.ub.es

Accepted 10 December 2001

\section{REFERENCES}

1 Chatham WW. Treatment of lupus with corticosteroids. Lupus 2001; 10:140-7.

2 Tan EM, Cohen AS, Fries JF, Masi AT, McShane DJ, Rothfield NF, et al. The 1982 revised criteria for the classification of systemic lupus erythematosus. Arthritis Rheum 1982:25:1271-7.

3 Patten SB, Neutel I. Corticosteroid-induced adverse psychiatric effects. Incidence, diagnosis and management. Drug Saf 2000;22:111-22.

4 Kohen M, Asherson RA, Gharavi AE, Lahita RG. Lupus psychosis: differentiation from the steroid-induced state. Clin Exp Rheumatol $1993 ; 11: 323-6$

5 Wysenbeek AJ, Leibovici L, Zoldan J. Acute central nervous system complications after pulse steroid therapy in patients with SLE. J Rheumatol 1990; 17:1695-6.

6 Boston Collaborative Drug Surveillance Program. Acute adverse reactions to prednisone in relation to dosage. Clin Pharmacol Ther 1972;13:694-8

7 ACR ad hoc committee on neuropsychiatry lupus nomenclature. The American College of Rheumatology nomenclature and case definitions for neuropsychiatry lupus syndromes. Arthritis Rheum 1999:42:599-608

8 Lewis GP, Jusko WJ, Burke CW, Graves L. Prednisone side-effects and serum-protein levels. Lancet 1971;ii:778-80.

9 Niewoehner DE, Erbland ML, Deupree RH, Collins D, Gross NJ, Light RW, et al. Effect of systemic glucocorticoids on exacerbations of chronic obstructive pulmonary disease. N Engl J Med 1999;340:1941-7.

\section{Autoantibodies against $\mathrm{Clg}$ : view on association between systemic lupus erythematosus disease manifestation and $\mathrm{Clq}$ autoantibodies}

\section{Monova, S Monov, K Rosenova, T Argirova}

A ivation of the complement system is the first step in the prevention of damage by immune complexes. Systemic lupus erythematosus (SLE) is the prototype of immune complex diseases. The classical pathway of the complement system is considered to be the most important pathway in immune complex clearance. This pathway may be activated by IgM- and IgG-containing immune complexes after binding to Clq. ${ }^{1}$

In 1984 autoantibodies to $\mathrm{Clq}$ (ClqAb) were reported to be present in serum of patients with SLE. ${ }^{2}$ The recognition that $\mathrm{Clq}$ may serve as a non-organ-specific autoantigen has attracted a growing number of investigators. ${ }^{3}$

We studied 42 patients ( 38 female, four male, aged 19-64) with SLE. Twenty eight (67\%) had proven renal biopsy lupus nephritis (two patients had WHO class II lesions, four had WHO class III, 18 had WHO class IV, four had WHO class V), $14(33 \%)$ patients had evidence of lupus pneumonitis, and 11 (26\%) central nervous system disease (table 1).

All patients were tested by both basic and subclass enzyme linked immunosorbent assays (ELISAs) for ClqAb using a modification of the method of Wisnieski and Jones. ${ }^{4}$ Whole Clq was purified from human plasma by the method of Tenner et al. ${ }^{5}$ Raised ClqAb titres were found in 18 (43\%) patients. Of the patients with ClqAb, 12 had renal manifestations of SLE $(10(83 \%)$ of them had focal or diffuse proliferative glomerulonephritis), six central nervous system disease, and five lupus pneumonitis. Patients with raised ClqAb titres were younger, seven of them were positive for antibodies to dsDNA. The magnitude of proteinuria was positively associated with the presence of ClqAb.

Selective complete Clq deficiency was established in seven of our patients (Nos 6, 11, 16, 18, 28, 32, 33); in two of them (Nos $18,28)$, clinical data showed the presence of SLE in the family.

Available serum samples testing positive for IgG ClqAb were analysed for ClqAb IgG subclass distribution. Six (33\%) of the 18 patients had IgG2 ClqAb only, 3/18 (17\%) patients had IgGl ClqAb only, and 9/18 (50\%) had both IgGl and IgG2 $\mathrm{ClqAb}$. Therefore, IgG2 ClqAb was present in $15 / 18(83 \%)$ patients. The subset of sera from patients with IgGl or IgG2 $\mathrm{ClqAb}$ was assayed for total serum IgGl and IgG2 levels by radial immunodiffusion. The mean total serum IgGl was 7.9 (4.5) $\mathrm{mg} / \mathrm{ml}$, the mean total serum IgG2 was 2.6 (1.4) $\mathrm{mg} / \mathrm{ml}$. The mean ratio of IgGl/IgG2 (3.4 (2.1)) was similar to that reported in the literature for disease free subjects. ${ }^{6}$ The percentage of IgG2 ClqAb relative to total IgG2 was significantly greater than the percentage of IgGl ClqAb relative to total IgGl $(0.03(0.06) \% v 0.01(0.02) \%$ respectively, $\mathrm{p}<0.005$, $t$ test). Thus in our patient group the IgG2 component of the autoantibody response to $\mathrm{Clq}$ was disproportionately enriched relative to the overall $\operatorname{IgG}$ 
Table 1 Basic clinicolaboratory parameters in study patients

\begin{tabular}{|c|c|c|c|c|c|c|}
\hline $\begin{array}{l}\text { No/sex/age } \\
\text { (years) }\end{array}$ & $\mathrm{ClqAb}$ & $\begin{array}{l}\text { Anti- } \\
\text { dsDNA }\end{array}$ & ANA & $\begin{array}{l}\text { Lupus nephritis/WHO class/ } \\
\text { proteinuria }(\mathrm{g} / 24 \mathrm{~h}(\mathrm{SD}))\end{array}$ & Pneumonitis & $\begin{array}{l}\text { Central nervous } \\
\text { system involvement }\end{array}$ \\
\hline $1 / F / 28$ & + & & & + WHO class IV (6.8 (2.4)) & + & \\
\hline $\begin{array}{l}2 / F / 19 \\
3 / F / 36\end{array}$ & + & + & + & + WHO class IV (8.7 (3.1)) & + & + \\
\hline $\begin{array}{l}4 / F / 25 \\
5 / F / 34\end{array}$ & + & & + & + WHO class $V(5.4(0.5))$ & & + \\
\hline $\begin{array}{l}6 / M / 33 \\
7 / F / 41\end{array}$ & & & & + WHO class II (2.1 (0.9)) & + & + \\
\hline $8 / F / 27$ & + & + & + & + WHO class IV (7.2 (3.4)) & & \\
\hline $\begin{array}{l}9 / F / 34 \\
10 / F / 50\end{array}$ & + & & & + WHO class IV (3.5 (1.4)) & & + \\
\hline $11 / F / 44$ & & & + & + WHO class IV (4.1 (1.5)) & & + \\
\hline $12 / F / 26$ & + & + & & + WHO class IV (4.4 (2.3)) & & \\
\hline $13 / F / 30$ & + & & & + WHO class $V(7.1(1.2))$ & + & + \\
\hline $14 / F / 64$ & & & + & $+\mathrm{WHO}$ class IV $(2.5(0.9))$ & + & \\
\hline $15 / F / 24$ & + & + & + & + WHO class IV (3.4 (1.7)) & & \\
\hline $\begin{array}{l}16 / F / 38 \\
17 / F / 40\end{array}$ & & & & + WHO class IV (1.2 (0.7)) & + & + \\
\hline $18 / F / 47$ & & + & + & + WHO class IV (2.4 (0.8)) & + & + \\
\hline $19 / F / 29$ & + & & & + WHO class IV (4.2 (1.3)) & + & \\
\hline $20 / F / 22$ & + & + & + & & & \\
\hline $21 / F / 34$ & + & & & + WHO class IIIB (3.8 (1.7)) & & \\
\hline $22 / F / 31$ & + & & & & & \\
\hline $\begin{array}{l}23 / F / 28 \\
24 / F / 42\end{array}$ & + & + & & + WHO class IV (5.3 (2.0)) & + & \\
\hline $25 / M / 36$ & + & + & + & + WHO class IIIB (4.8 (1.4)) & & \\
\hline $26 / F / 32$ & + & & & & & + \\
\hline $27 / F / 25$ & + & & & & & \\
\hline $28 / F / 31$ & & + & + & + WHO class IV (3.1 (1.7)) & + & \\
\hline $29 / F / 36$ & & & & & + & + \\
\hline $30 / F / 27$ & & & + & & & \\
\hline $31 / F / 23$ & + & & & & & \\
\hline $32 / M / 24$ & & + & + & + WHO class $V(4.0(1.1))$ & + & \\
\hline $33 / F / 34$ & & & & + WHO class IIIA (2.3 (0.8)) & + & \\
\hline $34 / F / 41$ & + & & & + WHO class IV (4.2 (2.3))" & & + \\
\hline $\begin{array}{l}35 / F / 28 \\
36 / F / 23\end{array}$ & & + & + & + WHO class IV $(3.0(0.6))$ & & \\
\hline $37 / M / 31$ & & + & + & $+\mathrm{WHO}$ class IV (2.4 (0.3)) & & \\
\hline $38 / F / 36$ & & & & + WHO class $V(1.7(0.3))$ & & \\
\hline $39 / F / 25$ & & & & + WHO class IV (1.7 (0.5)) & & \\
\hline $40 / F / 34$ & & & & + WHO class IIIB $(2.1(0.4))$ & & \\
\hline $41 / F / 27$ & & + & + & + WHO class IV (5.2 (2.6)) & & \\
\hline $42 / F / 20$ & & & & + WHO class $\|(0.9(0.3))$ & & \\
\hline
\end{tabular}

subclasses distribution, as no alteration in IgG subclass distribution was noted. The ClqAb in our group were predominantly of IgG2 and IgG1 subclasses. This distribution is consistent with that found by Wisnieski and Jones in a study characterising ClqAb in patients with SLE and hypocomplementaemic urticarial vasculitis, ${ }^{4}$ but contrasts with the IgG3 and IgG2 predominance reported by Coremans et al in patients with SLE.

The mechanisms mediating autoantibody pathogenicity remain unclear. It has been proposed that ClqAb may act systemically by up regulating activation of classical complement pathway. Alternatively, ClqAb may act locally within the renal glomerulus to enhance tissue injury initiated by immune complex deposition. The association of ClqAb with proliferative lupus nephritis is now well established, ${ }^{2}$ but the significance of ClqAb for lupus pneumonitis and cerebrovasculitis should be a target for future investigations.

\section{Authors' affiliations}

D Monova, S Monov, Department of Internal Medicine, Medical University, Sofia, Bulgaria

K Rosenova, T Argirova, Department of Biochemistry, Sofia University, Bulgaria
Correspondence to: Dr D Monova, Department of Internal Medicine, Medical University, University Hospital "St J Rilski", 15 D Nestorov St, 1431 Sofia, Bulgaria; dmonova@hotmail.com

Accepted 7 December 2001

\section{REFERENCES}

1 Cooper NZ. The classical complement pathway: activation and regulation of the first complement component. Adv Immunol 1985:37:151-216.

2 Uwatoko S, Aotsuka S, Okawa M, Egusa Y, Yokohari R, Aisawa C, K. Characterization of $\mathrm{Cl}$ q-binding $\mathrm{lgG}$ complexes in systemic lupus erythematosus. Clin Immunol Immunopathol 1984;30:104-16.

3 Siegert CEH, Kazatchkine MD, Sjoholm A, Wursner R, Loos M, Daha MR. Autoantibodies against $C l q$ : view on clinical relevance and pathogenic roles. Clin Exp Immunol 1999; 1 16:4-8.

4 Wisnieski JJ, Jones SM. Comparison of autoantibodies to the collagen-like region of $\mathrm{Clq}$ in hypocomplementemic urticarial vasculitis syndrome and systemic lupus erythematosus. J Immunol 1992; 148:1396-403.

5 Tenner AJ, Lesavre PH, Cooper NR. Purification and radiolabeling of human Clq. J Immunol 1981;127:648-53.

6 Schur P. IgG subclass - a review. Ann Allergy 1987:58:89-99.

7 Coremans IEM, Spronk PE, Bootsma H, Daha MR, van der Voort EAM, Kater $\mathrm{L}$, et al. Changes in antibodies to $\mathrm{Clq}$ predict renal relapses in systemic lupus erythematosus. Am J Kidney Dis 1995;26:505-601.

8 Moreland LW, Gay RE, Gay S. Collagen autoantibodies in patients with vasculitis and systemic lupus erythematosus. Clin Immunol Immunopathol $1991 ; 60: 412-18$. 


\title{
Silent thyroiditis associated with etanercept in rheumatoid arthritis
}

\author{
E Andrès, F-X Limbach, B Goichot, J Sibilia
}

r $\mathrm{n}$ recent years, monoclonal antibodies (infliximab) and a recombinant human tumour necrosis factor receptor (p75)-Fc fusion protein (TNFR:Fc) (etanercept) have been successfully used to treat rheumatoid arthritis (RA). ${ }^{1}$ These TNF blocking agents are now widely employed in patients with treatment resistant RA. TNF inhibitors are generally well tolerated with $<0.5 \%$ of patients developing a drug induced lupus syndrome, although 4-16\% may develop antibodies to double stranded DNA (dsDNA). Apart from two patients presenting autoimmune skin diseases associated with etanercept (discoid lupus and necrotising vasculitis), ${ }^{2}$ there are no other reports of well documented autoimmune disease. In this paper we describe the first case of silent autoimmune thyroiditis during TNFR:Fc treatment for severe RA.

\section{CASE REPORT}

A 43 year old woman followed up since 1991 for erosive RA had been successively treated with various disease modifying antirheumatic drugs (Allochrysine, D-penicillamine, and methotrexate) combined with low dose corticosteroids. In March 1998 she reported an important flare up despite corticosteroids ( $10 \mathrm{mg} /$ day) and methotrexate ( $15 \mathrm{mg} /$ week). Methotrexate was replaced by etanercept (25 mg twice a week), which led to a dramatic improvement after one month of treatment. The evaluation before TNFR-Fc treatment disclosed no evidence of thyroid disorders: the patient had no clinical features, serum thyroid stimulating hormone (TSH) and free thyroid hormones were normal, and thyroid antibodies were negative. No other autoantibody (anti-dsDNA, anticardiolipin, anti-extractable nuclear antigen (ENA)) was present except a high titre of IgM rheumatoid factor. In January 2000 the patient developed a non-tender moderate goitre. Thyroid evaluation disclosed modest hypothyroidism: serum TSH $6.3 \mathrm{mU} / \mathrm{ml}($ normal $<4.5)$ and serum free thyroxine (T4) $11 \mathrm{pmol} / \mathrm{l}$ (normal 11-23) (Elecsys assay). Titres of native antimicrosomal and antithyroglobulin antibodies were raised at $820 \mathrm{IU} / \mathrm{ml}$ (normal <60) and $230 \mathrm{IU} / \mathrm{ml}$ (normal <60), respectively (radioimmunoassay, Brahms). Anti-TSH receptor antibodies were negative $(<5 \mathrm{IU} / \mathrm{l}$, normal $<1 \mathrm{l})$ (Radio Receptor Assay, Brahms) and no other autoantibodies (antidsDNA, anticardiolipin, anti-ENA) were found except an IgM rheumatoid factor. A technetium-99m pertechnetate thyroid scintigraphic scan showed reduced uptake.

In the absence of other known cause, the diagnosis was silent thyroiditis induced by TNFR:Fc. Etanercept treatment was completed four months after the onset of hypothyroidism, and there was no aggravation of the thyroid disorder without hormonal substitution after a year and a half of follow up.

\section{DISCUSSION}

This report describes a case of silent autoimmune thyroiditis which developed during TNFR:Fc treatment in a patient with RA without evidence of previous thyroid disorders. Thyroiditis has not to our knowledge been described as a side effect of TNFR:Fc treatment and a causal relationship cannot formally be established in our case report. However, cytokines like interferon $\gamma$ or interleukin 2 often induce thyroiditis in patients with pre-existing autoimmune thyroid disease. T cell (Thl) depletion with monoclonal antibodies (Campath-1) can also lead to the development of antibody mediated thyroid autoimmunity. ${ }^{3}$ The mechanism of this effect of TNF blocking agents is not well understood, but modulation of the homing of Th1 and Th2 cells may explain the induction of autoimmune thyroiditis. ${ }^{45}$ In our opinion, TNFR:Fc treatment should be considered as a potential cause of drug induced autoimmune thyroiditis. Nevertheless, further studies are needed to estimate the incidence and the mechanism of this side effect.

\section{Authors' affiliations}

E Andrès, B Goichot, Department of Internal Medicine, University Hospital Strasbourg, France

F-X Limbach, J Sibilia, Department of Rheumatology, University Hospital Strasbourg

Correspondence to: Professor J Sibilia, Service de Rhumatologie, Avenue Molière, 67098 Strasbourg Cedex France; jean.sibilia@wanadoo.fr

Accepted 15 October 2001

\section{REFERENCES}

1 Weinblatt ME, Kremer JM, Bankhust AD, Bulpitt KJ, Fleischmann RM, Fox RI, et al. A trial of etanercept, a recombinant tumor necrosis factor receptor: Fc fusion protein, in patients with rheumatoid arthritis receiving methotrexate. N Engl J Med 1999:340:253-9.

2 Brion Ph, Mittal-Henckle A, Kalunien KC. Autoimmune skin rashes associated with etanercept for rheumatoid arthritis. Ann Intern Med 1999;131:634.

3 Coles AJ, Wing M, Smith S, Coraddu F, Greer S, Taylor C, et al. Pulsed monoclonal antibody treatment and autoimmune thyroid disease in multiple sclerosis. Lancet 1999;354:1691-5

4 Maurice MM, Van der Graaf WL, Leow A, Breedveld FC, van Lier RA Verweii CL. Treatment with monoclonal anti-tumor necrosis factor $\alpha$ antibody results in an accumulation of Th $1 \mathrm{CD} 4+\mathrm{T}$ cells in the peripheral blood of patients with rheumatoid arthritis. Arthritis Rheum 1999;42:2166-73.

5 Guo J, Rapoport B, McLachlan SM. Balance of Th 1/Th2 cytokines in thyroid autoantibody synthesis in vitro. Autoimmunity 1999;30:1-9. 


\title{
Synovial T cell proliferation to the Yersinia enterocolitica $19 \mathrm{kDa}$ antigen differentiates yersinia triggered reactive arthritis $(\operatorname{Re} A)$ from $\operatorname{ReA}$ triggered by other enterobacteria
}

\author{
H Appel, M Rudwaleit, P Wu, M Grolms, J Sieper, A Mertz
}

Ann Rheum Dis 2002;61:566-567

R eactive arthritis (ReA) mostly presents as an asymmetrical oligoarthritis, usually affecting the leg joints. ${ }^{1}$ It is a $\mathrm{T}$ cell dependent inflammatory disease following infections with various enteropathic bacteria-for example, Yersinia enterocolitica 0:3, Salmonella enteritidis, Shigella fexneri, or microbes pathogenic for the urogenital tract such as Chlamydia trachomatis. ${ }^{2}$ Identification of the structure of antigens of triggering microbes which drive immune responses in the synovial fluid would be of great interest.

We recently described two major antigens, the Ye $19 \mathrm{kDa}$ and the Ye HSP60 inducing synovial T cell proliferation in patients with Ye triggered ReA..$^{3-7}$ They seemed to overcome the specificity problem of proliferation assays with $\mathrm{T}$ cells cultured from the site of inflammation to ReA triggering bacteria, because the local immune response to whole bacteria is accompanied by a restricted specificity probably due to cross reactivity with common epitopes. ${ }^{8}$ Since Ye is the only known ReA triggering bacteria expressing the Ye $19 \mathrm{kDa}$ protein from the $\beta$ subunit of urease, ${ }^{6}$ we investigated the possibility that synovial T cell proliferation to this protein might help to differentiate Ye triggered arthritis from arthritides caused by other bacteria.

In view of this specificity problem it was not unexpected to find a large number of patients in our clinic who showed clinical features of ReA and had synovial T cell proliferation to two or more enteropathic bacteria.

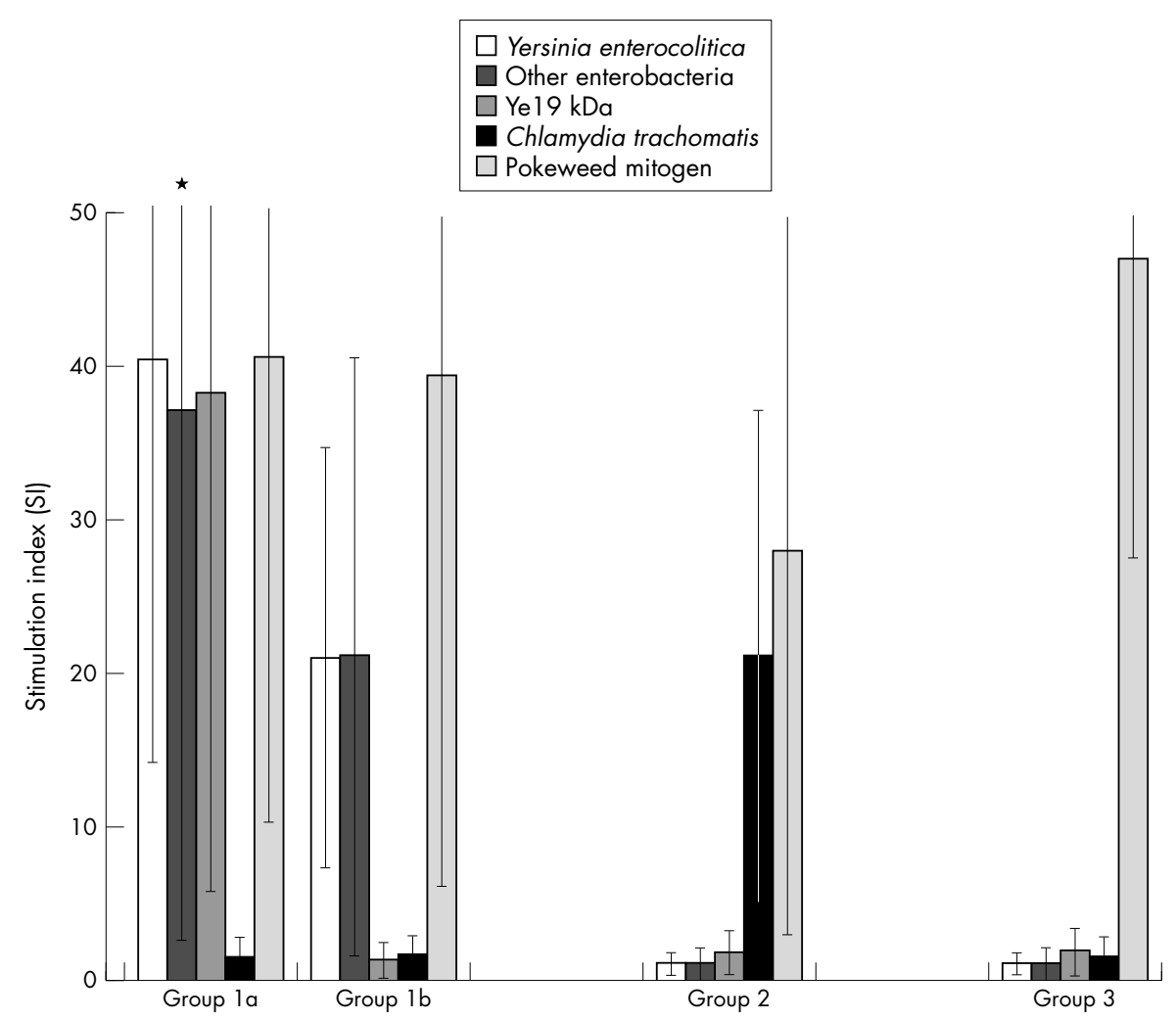

\section{METHODS}

We tested the synovial T cells of 66 patients with arthritis of one or more joints. Ye triggered ReA was diagnosed based on a typical history of previous symptomatic gastrointestinal infection or significant agglutinin titre. Chlamydia trachomatis triggered ReA was diagnosed in patients with arthritis and positive urogenital swabs or chlamydia-specific antibodies and a recent history of symptomatic urethritis or cervicitis. Synovial fluid mononuclear cells were cultured in the presence of heat inactivated bacterial antigens such as Yersinia enterocolitica, Salmonella enteritidis, Shigella flexneri, Campylobacter jejuni, and Chlamydia trachomatis. For stimulation with Ye $19 \mathrm{kDa}$ we used l $\mu \mathrm{g} / \mathrm{ml}$ recombinant protein, which was expressed as described previously. ${ }^{4}$ Stimulation indices were calculated in comparison with background activity by $\mathrm{T}$ cell medium. A stimulation index (SI) of $>5$ was classified as positive.

\section{RESULTS}

We identified 11 (28\%) subjects among the 40 patients with T cell proliferation to Ye (mean (SD) SI 39.88 (30.22)) and at least to one more enterobacterium (SI 36.87 (34.62)), who responded also to Ye $19 \mathrm{kDa}$ (SI 38.34 (32.97)) (group la), whereas 29 patients (Ye: SI 21.06 (16.71), other enterobacteria: SI 21.81 (20.23)) had no cellular immune response to Ye 19 kDa (SI 1.77 (1.27)) (group lb, fig l). We performed the same

Figure 1 Synovial T cell response to whole Yersinia enterocolitica (Ye) and recombinant Ye $19 \mathrm{kDa}$ helps to differentiate yersinia triggered reactive arthritis $(\operatorname{Re} A)$ from $\operatorname{Re} A$ triggered by other bacteria. The synovial T cell proliferation to Ye 19 $\mathrm{kDa}$ protein was analysed in 66 patients with ReA. *Highest value for any enterobacterium other than yersinia. 
experiment with synovial $\mathrm{T}$ cells from 11 patients with chlamydia triggered ReA (SI 20.8 (15.51)) (group 2). In this case none of the patients had a T cell proliferation to Ye $19 \mathrm{kDa}$ (SI 1.72 (1.5)) (fig 1). In 15 patients with the clinical diagnosis of ReA or undifferentiated oligoarthritis synovial $\mathrm{T}$ cells proliferated to mitogen, but not to any of the ReA triggering bacteria or Ye $19 \mathrm{kDa}$ (SI 1.78 (1.25)) (group 3, fig 1).

Because the Ye $19 \mathrm{kDa}$ as the $\beta$ subunit of urease ${ }^{6}$ is a yersinia antigen not shared by other ReA triggering enterobacteria we believe that we have identified the cause of disease of a substantial number of patients with ReA in clinical practice which would not have been known by other means. We assume that Ye $19 \mathrm{kDa}$ used in synovial $\mathrm{T}$ cell proliferation assays is a useful antigen to specify Ye as the disease triggering bacteria and might be of diagnostic value in ReA.

\section{Authors' affiliations \\ H Appel, M Rudwaleit, P Wu, M Grolms, J Sieper, Benjamin Franklin Medical Centre, Division of Gastroenterology and Rheumatology, Free University Berlin, Germany \\ P Wu, J Sieper, Deutsches Rheumaforschungszentrum Berlin, Germany A Mertz, Medical Centre Augsburg, Division of Nephrology, Augsburg, Germany}

Correspondence to: Professor J Sieper; hisieper@zedat.fu-berlin.de

Accepted 17 December 2001

\section{REFERENCES}

1 Toivanen P, Toivanen A, Olkkonen L, Aantaa S. Hospital outbreak of Yersinia enterocolitica infection. Lancet 1973;i:801-3.

2 Sieper J, Kingsley G. Recent advances in the pathogenesis of reactive arthritis. Immunol Today 1996;17:160-4.

3 Appel H, Mertz A, Distler A, Sieper J, Braun J. The 19kD protein of Yersinia enterocolitica is recognized on the cellular and humoral level by patients with yersinia induced reactive arthritis. J Rheumatol 1999:26:1964-71.

4 Mertz AKH, Ugrinovic S, Lauster R, Wu P, Grolms M, Böttcher U, et al. Characterization of the synovial $T$ cell response to various recombinant yersinia antigens in Yersinia enterocolitica triggered reactive arthritis. Arthritis Rheum 1998;41:315-26.

5 Mertz AKH, Wu P, Sturniolo T, Stoll D, Rudwaleit $M$, Lauster $R$, et al. Multispecific CD4+ T cell response to a single 12-mer epitope of the immunodominant heat-shock protein 60 of Yersinia enterocolitica in yersinia-triggered reactive arthritis: overlap with B27-restricted CD8 epitope, functional properties and epitope presentation by multiple DR alleles. J Immunol 2000;164:1529-37.

6 Skurnik M, Batsford SR, Mertz A, Schiltz E, Toivanen P. The putative arthritogenic cationic $19 \mathrm{kD}$ antigen of Yersinia enterocolitica is a urease $\beta$-subunit. Infect Immun 1993;61:2498-503.

7 Mertz AKH, Batsford SR, Curschellas E, Kist M, Gondolf KB. Cationic yersinia-induced chronic allergic arthritis in rats; a model for reactive arthritis in humans. J Clin Invest 1991;88:632-42.

8 Kaluza W, Meyer zum Buschenfelde KH, Galle PR, Marker-Hermann E. Synovial fluid lymphocyte proliferation in response to crude microbial antigens is not useful as a diagnostic test to specifically indicate a bacterial cause of arthritis. Clin Exp Rheumatol 2000;18: $39-46$

\section{Leflunomide and hypertension}

\section{B Rozman, S Praprotnik, D Logar, M Tomšič, M Hojnik, M Kos-Golja, R Accetto, P Dolenc}

eflunomide is a new isoxazole drug with disease modifying properties for the treatment of rheumatoid arthritis (RA). Hypertension has been mentioned as a common side effect of the treatment. It was found in up to $10.6 \%$ of patients receiving $25 \mathrm{mg}$ leflunomide in a phase II study. ${ }^{1}$ New onset hypertension occurred in $3.7 \%$ of patients in a phase III European study, and in $2.1 \%$ of patients, with a mean increase in systolic and diastolic blood pressure of 2.2 and $1.9 \mathrm{~mm} \mathrm{Hg}$, respectively, in an American phase III study. ${ }^{3}$ There was no evidence that hypertension was related to an impairment of renal function or proteinuria. The changes in blood pressure during leflunomide treatment have not been studied in detail.

\section{PATIENTS AND METHODS}

Thirty consecutive patients fulfilling the American Rheumatism Association criteria for RA were recruited into a prospective study and treated with standard doses of leflunomide. Other enrolment criteria included stable treatment with non-steroidal anti-inflammatory drugs up to the maximum recommended dose and/or corticosteroid treatment up to $10 \mathrm{mg} /$ day for at least three months before starting treatment with leflunomide. The patients were followed up at two week intervals. A trained nurse according to the Slovenian and WHO/ISH hypertension guidelines measured blood pressure. ${ }^{4}$ Automatic oscillometric monitors (Spacelabs 90209) were used for ambulatory blood pressure monitoring (ABPM). ${ }^{5}$ Seventeen patients finished the study according to the protocol with 6.5 (1) months between the two ABPM procedures.

\section{RESULTS}

A statistically significant increase in conventional blood pressure measurements of both systolic and diastolic blood pressure was seen (table 1). The rise in systolic blood pressure was seen relatively early-in 2-4 weeks (from 127.03 (20.2) $\mathrm{mm} \mathrm{Hg}$ to 134.1 (24.3) $\mathrm{mm} \mathrm{Hg}, \mathrm{p}=0.034)$. On the contrary, the rise in diastolic blood pressure was not significant after 2-4 and 6-8 weeks, respectively. In 7/17 patients, the initially normal blood pressure values exceeded the systolic and/or diastolic blood pressure values of 140/90 $\mathrm{mm} \mathrm{Hg}$ in the follow up measurements. Moreover, in four patients the systolic blood pressure was, at least once in the follow up period, more than $40 \mathrm{~mm} \mathrm{Hg}$ and diastolic blood pressure more than $20 \mathrm{~mm} \mathrm{Hg}$ above the initial values. According to the ambulatory blood pressure monitoring (ABPM) measurements the overall trend after the start of leflunomide treatment was an increase in both systolic and diastolic blood pressure and heart rate, which was highly statistically significant (table 1). Figure 1 shows individual changes in blood pressure and heart frequency.

\section{DISCUSSION}

Using standardised conditions of blood pressure measuring (not the case in phase II and phase III clinical trials) and ABPM, we confirmed the blood pressure rises during treatment with leflunomide. Adding to the knowledge from previous studies, we showed that a statistically significant rise in systolic blood pressure was apparent already after 

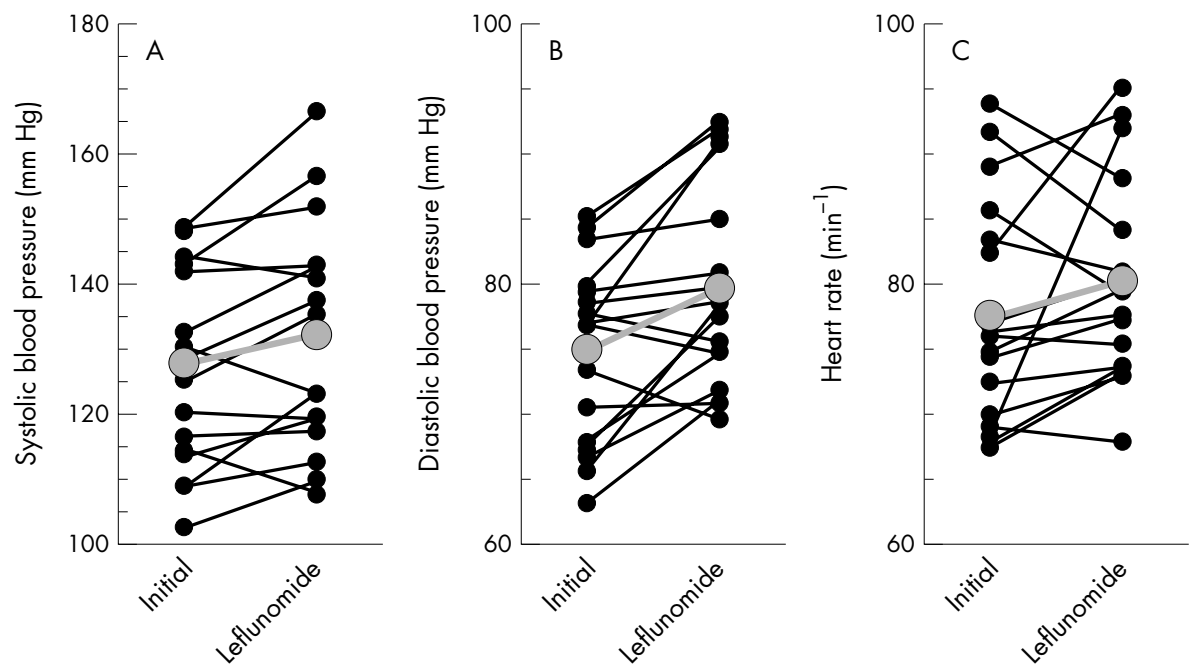

Figure 1 Changes in (A) systolic blood pressure, (B) diastolic blood pressure, and (C) heart rate in 17 patients with RA treated with leflunomide. Twenty four hour averages of individual patients during ABPM performed during and after 6.5 (1) months of treatment with leflunomide are shown. The overall trends in individual variables are shown by the grey line.

2-4 weeks of the treatment, thus pointing to the need for early blood pressure monitoring. By contrast, the rise in diastolic blood pressure appeared later. Hypertensive values in individual patients suggest that regular measuring of blood pressure is required during treatment with leflunomide.

Employing ABPM, we confirmed the significant rise in blood pressure during the leflunomide treatment, thus making the role of the "white coat" phenomenon unlikely. It should be mentioned that it has been confirmed that non-invasive ABPM has no effect on blood pressure because of discomfort during cuff inflation. We are also not aware of any special device developed to measure blood pressure in patients with painful limbs. However, as a clinically relevant $(>5$ joints) improvement in tender and swollen joint count was seen in $14(83 \%)$ of the 17 patients analysed, the degree of pain imposed by blood pressure measurements and its effect on blood pressure were expected to decrease rather than rise during the study.

The results do not allow us to speculate on the mechanism of the blood pressure increase associated with the leflunomide treatment. As the heart rate also rises during leflunomide treatment, it has been assumed that hypertension may be caused by an increased sympathetic drive.

Table 1 Conventional systolic and diastolic blood pressure measurements, 24 hour averages of blood pressure, and heart frequency before (initial ABPM) and after treatment with leflunomide (final $A B P M$ ) in 17 patients with rheumatoid arthritis. Twenty four hour, day time $(600 \mathrm{am}$ to $1000 \mathrm{pm})$, and night time $(1000 \mathrm{pm}$ to 6 $00 \mathrm{am})$ mean values and standard deviations are shown. Statistical significance of differences was tested with Student's $t$ test. $p$ Values of $\leqslant 0.05$ were considered significant

\begin{tabular}{|c|c|c|c|c|}
\hline & $\begin{array}{l}\text { Initial } \\
\text { measurement }\end{array}$ & $\begin{array}{l}\text { Final } \\
\text { measurement }\end{array}$ & $t$ Test & $\begin{array}{l}\text { Significance } \\
\text { (p) }\end{array}$ \\
\hline \multicolumn{5}{|l|}{ Conventional measurements (mean) } \\
\hline Systolic blood pressure $(\mathrm{mm} \mathrm{Hg})$ & $127.3(20.2)$ & $140.7(20.1)$ & 3.55 & 0.003 \\
\hline Diastolic blood pressure (mm Hg) & $76.7(9.3)$ & $84.0(8.6)$ & 3.08 & 0.007 \\
\hline \multicolumn{5}{|l|}{$\mathrm{ABPM}$ (mean) } \\
\hline Systolic blood pressure (mm Hg) & 127.8 (19.7) & $132.1(21.4)$ & 3.01 & 0.003 \\
\hline Diastolic blood pressure $(\mathrm{mm} \mathrm{Hg})$ & $74.9(12.4)$ & $79.7(13.0)$ & 5.43 & 0.000 \\
\hline Mean arterial pressure $(\mathrm{mm} \mathrm{Hg})$ & $93.6(14.8)$ & $98.7(15.8)$ & 4.76 & 0.000 \\
\hline Pulse pressure $(\mathrm{mm} \mathrm{Hg})$ & $52.9(14.0)$ & $52.4(15.5)$ & 0.46 & NS \\
\hline Heart frequency $\left(\mathrm{min}^{-1}\right)$ & $77.6(13.7)$ & $80.2(13.5)$ & 2.71 & 0.007 \\
\hline \multicolumn{5}{|l|}{ Day time $(600 \mathrm{am}$ to $1000 \mathrm{pm})$} \\
\hline Systolic blood pressure (mm Hg) & $130.2(18.2)$ & $135.2(19.6)$ & 5.18 & 0.000 \\
\hline Diastolic blood pressure $(\mathrm{mm} \mathrm{Hg})$ & $77.8(11.4)$ & $83.1(11.7)$ & 9.04 & 0.000 \\
\hline Mean arterial pressure $(\mathrm{mm} \mathrm{Hg})$ & $96.1(13.4)$ & $83.1(11.7)$ & 7.86 & 0.000 \\
\hline Pulse pressure $(\mathrm{mm} \mathrm{Hg})$ & $52.5(14.2)$ & $52.1(15.4)$ & 0.44 & NS \\
\hline Heart frequency $\left(\mathrm{min}^{-1}\right)$ & 81.8 (13.7) & 83.7 (13.3) & 2.83 & 0.005 \\
\hline \multicolumn{5}{|l|}{ Night time (1000 pm to $600 \mathrm{am})$} \\
\hline Systolic blood pressure $(\mathrm{mm} \mathrm{Hg})$ & $121.9(20.6)$ & $124.1(20.6)$ & 1.20 & NS \\
\hline Diastolic blood pressure $(\mathrm{mm} \mathrm{Hg})$ & $69.1(12.2)$ & $72.3(11.8)$ & 3.07 & 0.002 \\
\hline Mean arterial pressure $(\mathrm{mm} \mathrm{Hg})$ & $87.8(15.5)$ & 91.5 (14.6) & 2.77 & 0.006 \\
\hline Pulse pressure $(\mathrm{mm} \mathrm{Hg})$ & $52.8(13.3)$ & $51.7(15.0)$ & 0.86 & NS \\
\hline Heart frequency $\left(\mathrm{min}^{-1}\right)$ & $68.7(9.2)$ & $72.9(10.9)$ & 4.78 & 0.000 \\
\hline
\end{tabular}


This hypothesis remains to be tested. The changes in the raised blood pressure after six months of leflunomide treatment will be clarified after the final report of all extended studies.

\section{Authors' affiliations}

B Rozman, S Praprotnik, D Logar, M Tomšič,

M Hojnik, M Kos-Golia, Department of Rheumatology, Medical Centre

Liubljana, Vodnikova 62, 1000 Ljubliana, Slovenia

R Accetto, P Dolenc Department of Hypertension, Medical Centre

Ljubliana

Correspondence to: Dr B Rozman; kc.lj.rozman@siol.net

Accepted 10 December 2001

\section{REFERENCES}

1 Rozman B, for the Leflunomide Investigator's Group. Clinical experience with leflunomide in rheumatoid arthritis. J Rheumatol 1998;25/suppl 53):27-32

2 Smolen JS, Kalden JR, Rozman B, Kvien T, Scott DL, Larsen A, et al. Efficacy and safety of leflunomide compared to placebo and sulfasalazine in active rheumatoid arthritis. A double-blind, randomized, multicenter study Lancet 1999.353:259-66.

3 Strand V, Cohen S, Schiff M, Weaver A, Fleischmann R, Cannon G, et al. Treatment of active rheumatoid arthritis with leflunomide compared with placebo and methotrexate. Arch Intern Med 1999;159:2542-50.

$4 \mathrm{WHO} / \mathrm{ISH}$. The $1999 \mathrm{WHO} / \mathrm{ISH}$ hypertension guidelines. J Hypertens $1999 \cdot 17: 151-83$.

5 O'Brien E, Coats A, Owens P, Petrie J, Padfield PL, Littler WA, et al. Use and interpretation of ambulatory blood pressure monitoring: recommendations of the British Hypertension Society. BM 2000:320:1128-34

\title{
Adhesion molecule expression in the synovial membrane of psoriatic arthritis
}

\author{
V Riccieri, A Spadaro, E Taccari, A Zoppini, E Koo, J Ortutay, M Sesztak, I Markus
}

Ann Rheum Dis 2002;61:569-570

E ndothelium may play a part in the pathogenesis of longstanding psoriatic arthritis (PsA), ${ }^{1}$ whereas a higher vascularisation and a less intense adhesion molecule expression have been found in PsA synovial membrane compared with rheumatoid arthritis. ${ }^{2}$ Some proinflammatory molecules, such as tumour necrosis factors (TNFs), can induce synovial endothelial cells and fibroblast-like synoviocytes to express adhesion molecules. ${ }^{3}$

\section{PATIENTS AND METHODS}

In two groups of patients with PsA-eight patients with synovitis of $<1$ year and six patients with synovitis $>1$ year-we studied the expression and pattern of the synovial distribution of endothelial leucocyte adhesion molecule-1 (ELAM-1 or E-selectin) (CD62E), intercellular adhesion molecule-1 (ICAM-1) (CD54), vascular cell adhesion molecule-1
(VCAM-1) (CD 106) (Immunotech, Marseille, France), and of TNF $\alpha$ and TNF $\beta$ cytokines (Chemicon International, Temecula, CA, USA) using a standard three stage immunoperoxidase labelling technique (LAB VISION, Fremont, CA, USA). ${ }^{5}$ The lining layer, the infiltrating elements, and the endothelial cells were evaluated for the number of positive cells per high power field $(\times 40)$.

\section{RESULTS}

Table 1 summarises the main clinical and laboratory data of the two groups; no significant clinical or laboratory differences were seen.

E-selectin was present more often at endothelial, cellular infiltrate, and lining layer levels in $7 / 8(88 \%)$ patients with a disease duration $<1$ year, where only $3 / 6$ patients $(50 \%)$ with disease duration $>1$ year were positive. ICAM-1 was

Table 1 Main clinical and demographic features of 14 patients with PsA with a disease duration of less (group 1) or more (group 2) than one year

\begin{tabular}{|c|c|c|c|c|c|c|c|c|c|c|}
\hline $\begin{array}{l}\text { Patient } \\
\text { number }\end{array}$ & Sex & $\begin{array}{l}\text { Age } \\
\text { (years) }\end{array}$ & $\begin{array}{l}\text { Duration of } \\
\text { arthritis (years) }\end{array}$ & $\begin{array}{l}\text { Duration of } \\
\text { psoriasis (years) }\end{array}$ & PASI & $\begin{array}{l}\text { Ritchie } \\
\text { index }\end{array}$ & Subgroup & $\begin{array}{l}\mathrm{CRP} \\
(\mathrm{mg} / \mathrm{l})\end{array}$ & $\begin{array}{l}\text { ESR } \\
(\mathrm{mm} / 1 \mathrm{st} \mathrm{h})\end{array}$ & Treatment \\
\hline \multicolumn{11}{|l|}{ Group 1} \\
\hline 1 & $\mathrm{~F}$ & 60 & $<1$ & 1 & 3.2 & 17 & Polyarthritis & 5 & 14 & NSAIDs \\
\hline 2 & $\mathrm{~F}$ & 28 & $<1$ & 1 & 4.5 & 11 & Polyarthritis & 4 & 28 & NSAIDs \\
\hline 3 & $\mathrm{~F}$ & 48 & $<1$ & $<1$ & 0.3 & 3 & Oligoarthritis & 35 & 52 & Steroids \\
\hline 4 & M & 37 & $<1$ & 4 & 0.9 & 18 & Polyarthritis & 6 & 8 & NSAIDs \\
\hline 5 & $M$ & 31 & $<1$ & 2 & 0.3 & 9 & Polyarthritis & 12 & 24 & None \\
\hline 6 & $\mathrm{~F}$ & 35 & $<1$ & 1 & 9.0 & 20 & Polyarthritis & 24 & 66 & NSAIDs \\
\hline 7 & $\mathrm{~F}$ & 25 & $<1$ & 19 & 2.1 & 5 & Oligoarthritis & 6 & 16 & HCQ/NSAIDs \\
\hline 8 & $\mathrm{~F}$ & 35 & $<1$ & 18 & 0.9 & 15 & Polyarthritis & 6 & 23 & $\mathrm{HCQ} / \mathrm{NSAIDs}$ \\
\hline \multicolumn{11}{|l|}{ Group 2} \\
\hline 1 & $M$ & 35 & 2 & 10 & 3.1 & 9 & Polyarthritis & 21 & 38 & NSAIDs \\
\hline 2 & $M$ & 36 & 5 & 13 & 6.6 & 10 & Polyarthritis & 80 & 86 & MTX/steroids \\
\hline 3 & $M$ & 53 & 3 & 37 & 8.9 & 21 & Polyarthritis & 6 & 3 & NSAIDs \\
\hline 4 & $M$ & 39 & 3 & 2 & 1.2 & 9 & Polyarthritis & 25 & 11 & SSZ \\
\hline 5 & $M$ & 43 & 5 & 30 & 4.2 & 6 & Oligoarthritis & 6 & 8 & NSAIDs \\
\hline 6 & $M$ & 50 & 10 & 25 & 9.0 & 15 & Polyarthritis & 6 & 10 & NSAIDs \\
\hline
\end{tabular}

PASI, Psoriasis Areas Severity Index; CRP, C reactive protein; ESR, erythrocyte sedimentation rate (Westergren); NSAIDs, non-steroidal anti-inflammatory drugs; HCQ, hydroxychloroquine; MTX, methotrexate; SSZ, sulfasalazine. 


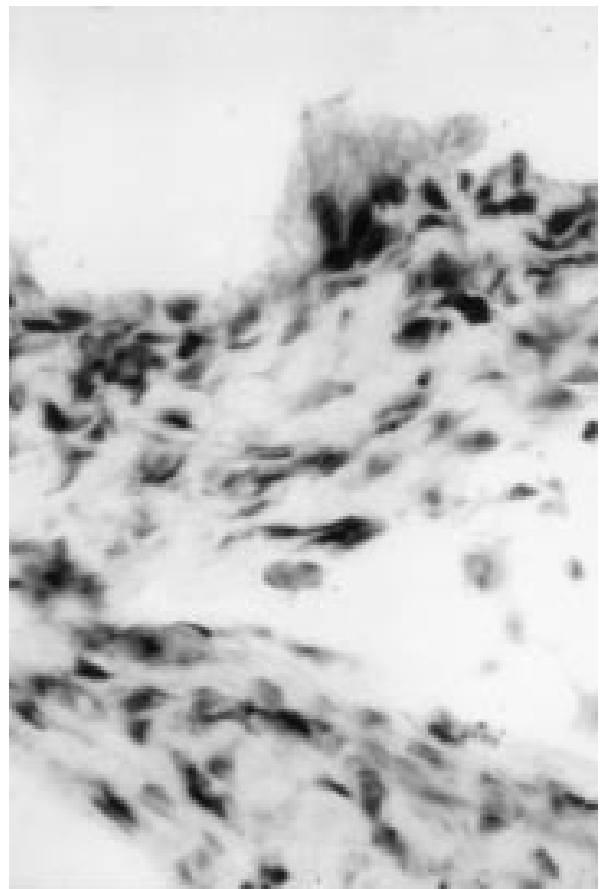

Figure 1 Representative specimen from the synovial membrane of a patient with psoriatic arthritis of $<1$ year; staining with ICAM-1 using monoclonal antibody CD54. Antigen positive cells are present throughout the entire specimen (original magnification $\times 250$ )

overexpressed in the lining layer of the early synovitic specimens compared with the longstanding samples ( $100 \% \mathrm{v}$ $33 \% ; \mathrm{p}<0.001$ ) (fig l ). On the contrary, VCAM-1 positivity was more commonly found in patients with longstanding PsA (5/5 $(100 \%) \vee 4 / 7(57 \%))$. Cells containing TNF $\alpha$ and TNF $\beta$ were consistently found in the synovial lining layer, in the infiltrates, and in the blood vessels, with no appreciable difference between the two groups.

\section{DISCUSSION}

Our results show that longstanding psoriatic synovitis may reduce the E-selectin expression, as already found in different forms of synovitis, ${ }^{7}$ and confirms the presence of ICAM- 1 and VCAM-1 positivity in PsA, as already described. ${ }^{2}$ As ICAM-1 was present in vessel walls in all tissue samples, this supports the view that this adhesion molecule is not only constitutively expressed on endothelial cells but is also increased during activation and is the most important adhesion molecule for cell binding to endothelium in inflamed tissue. ${ }^{7}$ VCAM-1 expression, generally absent on normal synovium, is found on activated endothelium and its up regulation has been recently implicated in various pathological conditions. ${ }^{8}$

The different expression of these adhesion molecules seems to be connected to the disease duration. A more frequent positivity for E-selectin, and partly for ICAM-1, in earlier synovitis compared with longstanding disease, where VCAM-1 expression was constantly found, shows for the first time how these molecules may separately participate in the synovitic process in the different phases of PsA, with a changing involvement as the disease evolves.
The presence of TNF $\alpha$ and TNF $\beta$, together with E-selectin, ICAM-1, and VCAM-1 positivity in the same samples, confirms the ability of TNFs to induce the expression of such adhesion molecules. ${ }^{3}$ Their localisation on the endothelial cells also suggests that these cells can produce TNFs, indicating the involvement of TNFs in the regulation of cell adhesion before migration into diseased joints. Our findings gain more importance in view of a recent immunohistochemical study, which showed a convincing effect of anti-TNF treatment on synovium in spondyloarthropathy, suggesting immunomodulatory mechanisms involving adhesion molecule expression. ${ }^{9}$

In conclusion, the variations in the presence of some adhesion molecules and TNFs shown in our study, partly related to disease duration, indicate their relative importance in mediating the succeeding mechanisms of psoriatic synovitis. This should be taken into account in the assessment of disease progression and in developing possible new therapeutic approaches.

Authors' affiliations

V Riccieri, A Spadaro, E Taccari, A Zoppini, Rheumatology Unit, Department of Medical Therapy, University of Rome "La Sapienza", Rome, Italy

E Koo, J Ortutay, Polyclinic of the Hospitaller Brothers of St John of God, Budapest, Hungary

M Sesztak, I Markus, National Institute of Rheumatology and Physiotherapy, Budapest, Hungary

Correspondence to: Dr V Riccieri, Rheumatology Unit, Department of Medical Therapy, University of Rome "La Sapienza", P le Aldo Moro 5, 00185 , Rome, Italy; valeria.riccieri@tin.it.

Accepted 10 December 2001

\section{REFERENCES}

1 Taccari E, Fattorossi A, Moretti S, Riccieri V, Fasani M, Zoppini A Phenotypic profile of major synovial cell populations in longstanding psoriatic arthritis. J Rheumatol 1987; 14:525-30

2 Veale D, Yanni G, Rogers S, Barnes L, Bresnihan B, Fitzgerald O. Reduced synovial membrane macrophage numbers, ELAM-1 expression, and lining layer hyperplasia in psoriatic arthritis as compared with rheumatoid arthritis. Arthritis Rheum 1993;36:893-900.

3 Abbot SE, Kaul A, Stevens CR, Blake DR. Isolation and culture of synovial microvascular endothelial cells: characterization and assessment of adhesion molecule expression. Arthritis Rheum 1992;35:401-6.

4 Marlor CW, Webb DL, Bombara MP, Greve JM, Blue ML. Expression of vascular cell adhesion molecule-1 in fibroblast-like synoviocytes after stimulation with tumor necrosis factor. Am J Pathol 1992;140:1055-60.

5 Hsu SM, Raine L, Fanger H. Use of avidin-biotin-immunoperoxidase complex $(A B C)$ in immunoperoxidase techniques: a comparison between $A B C$ and unlabelled antibody) (PAP) procedures. J Histochem Cytochem $1981 ; 29: 577-80$

6 Grom AA, Murray KJ, Luyrink L, Emery H, Passo MH, Glass DN, et al. Patterns of expression of tumor necrosis factor $\alpha$, tumor necrosis factor $\beta$, and their receptors in synovia of patients with juvenile rheumatoid arthritis and juvenile spondylarthropathy. Arthritis Rheum 1996;39:1703-10.

7 Mellbye OJ, Shen Y, Hogasen K, Mollnes TE, Forre O. Adhesion molecule expression and complement activation in vessel walls in synovial tissue from patients with chronic inflammatory joint disease. Clin Rheumatol 1996; 15:441-7.

8 Mojcik CF, Shevach EM. Adhesion molecules. A rheumatologic perspective. Arthritis Rheum 1997;40:991-1004.

9 Baeten D, Kruithof E, Van den Bosch F, Demetter P, Van Damme N, Cuvelier C, et al. Immunomodulatory effects of anti-tumor necrosis factor $\alpha$ therapy on synovium in spondyloarthropathy. Histologic findings in eight patients from an open-label pilot study. Arthritis Rheum 2001;44:186-95. 


\title{
Headache as the initial presentation of Wegener's granulomatosis
}

\author{
I G S Lim, P J Spira, H P McNeil
}

Ann Rheum Dis 2002;61:571-572

n Wegener's granulomatosis (WG), neurological involvement is rare at onset. We present an unusual case where headache was the initial, dominant presentation of WG.

\section{CASE REPORT}

A 34 year old white man presented with a three month history of headache. The headaches were migratory, throbbing, and were accentuated with head movement. Physical examination was normal. Computed tomography (CT) of the sinuses was normal. The patient was diagnosed with non-specific vascular headaches, and was prescribed pizotifen, which alleviated his headaches.

One month later, the patient developed a red right eye. Bilateral papilloedema was noted. He was now unable to work because of the headache. Magnetic resonance imaging (MRI) of the brain disclosed a normal ventricular system, but pronounced gadolinium enhancement of the meninges around the entire left hemisphere, most of the parieto-occipital region on the right, as well as the tentorium bilaterally (fig 1). Lumbar puncture disclosed a high cerebrospinal fluid (CSF) opening pressure of $27 \mathrm{~cm}(13-18 \mathrm{~cm})$. A CSF examination was entirely normal and cultures were negative. The headache was partially relieved by CSF drainage, and acetazolamide was started.

One week later, the patient developed a red left eye and left knee arthritis. Over the course of the next week, his condition progressed rapidly with purpuric lesions appearing on his hands and feet, followed by pericarditis and pulmonary haemorrhage. Biopsy of the purpura disclosed leucocytoclastic vasculitis. Antineutrophil cytoplasmic antibody (cANCA) taken at the time that he complained of the red left eye was positive at a titre of $1 / 80$, with specificity for proteinase-3. A week later, repeat testing showed that cANCA had risen to

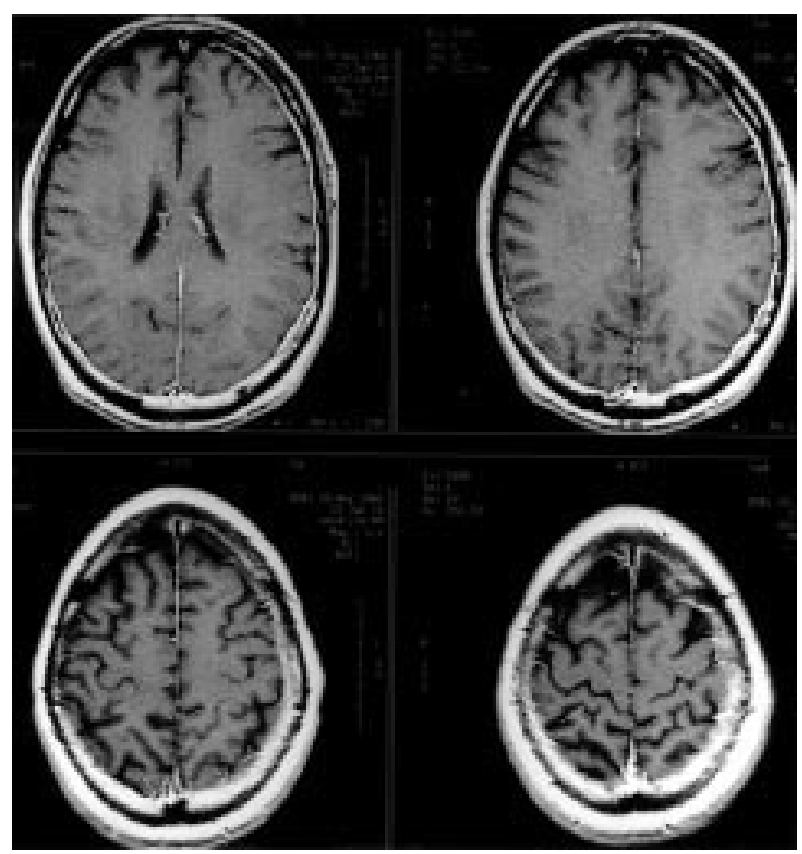

Figure 1 MRI showing diffuse meningeal enhancement.
$1 / 320$. There was also a mild normochromic, normocytic anaemia, and raised inflammatory markers. Urine analysis disclosed microscopic haematuria and mild proteinuria. No casts were identified. A CSF examination was again normal, but the opening pressure had risen to $36 \mathrm{~cm}$. WG was diagnosed.

Treatment was started with a $1 \mathrm{~g}$ pulse of intravenous methylprednisone, followed by oral daily doses of $1 \mathrm{mg} / \mathrm{kg}$ prednisone and $2 \mathrm{mg} / \mathrm{kg}$ cyclophosphamide. A few days after the start of treatment, the headaches had resolved and the CSF opening pressure was normal. Six months later, the patient is symptom-free, the papilloedema has resolved, MRI is normal, and the patient has returned to full-time work.

\section{DISCUSSION}

It is rare for WG to present with neurological symptoms. Neurological presentations described include ataxia, ocular nerve palsies, seizures, and deteriorating mental status. ${ }^{1-4}$ Shiotani et al described a 37 year old man with chronic sinusitis, who presented with fever and headache for 10 days before CT disclosed subdural and paranasal masses with marked thickening of the nasal mucosa. ${ }^{5}$ Our patient presented far more insidiously, with significant headache that persisted and worsened with time. The headache had clear vascular features but, beyond this, was non-specific. It was only four months later that musculoskeletal, cutaneous, ophthalmic, and cardiorespiratory features developed. Although neurological involvement may eventually develop in $33.6 \%$ of patients with WG, meningeal involvement, as gauged by meningeal enhancement on MRI or by biopsy is particularly uncommon, being recorded in only a handful of case reports. $.^{2-5} 7-10$ There also seems to be no relation between CSF abnormalities, clinical symptoms, or extent of meningeal involvement on MRI. ${ }^{7}$ A CSF examination may show no abnormality ${ }^{34}$ or a pleocytosis. ${ }^{3589}$ High opening pressures are unusual but have been described. ${ }^{10}$

In conclusion, we have presented a case of WG with extensive meningeal involvement. The exceptional feature in this case is the fact that headache was the sole symptom of the disease over several months, before a dramatic activation of the disorder with more typical features of WG.

\section{Authors' affiliations}

I G S Lim, H P McNeil, Department of Rheumatology, Prince of Wales Hospital, and University of New South Wales, Sydney, Australia 2052 P J Spira, Institute of Neurological Sciences, Prince of Wales Hospital

Correspondence to: Associate Professor H P McNeil, Department of Rheumatology, Prince of Wales Hospital, Randwick, New South Wales, Australia 2031; p.mcneil@unsw.edu.au

Accepted 13 December 2001

\section{REFERENCES}

1 Atcheson SG, Van Horn G. Subacute meningitis heralding a diffuse granulomatous angiitis: (Wegener's granulomatosis?). Neurology 1977;27:262-4.

2 Weinberger LM, Cohen ML, Remler BF, Naheedy MH, Leigh RJ. Intracranial Wegener's granulomatosis. Neurology 1993;43:1831-4.

3 Newman NJ, Slamovits TL, Friedland S, Wilson WB. Neuro-ophthalmic manifestations of meningocerebral inflammation from the limited form of Wegener's granulomatosis. Am J Ophthalmol 1995;120:613-21.

4 Burrell HC, McConachie NS. Pachymeningitis in Wegener's granulomatosis. Australas Radiol 1998;42:364-6. 
5 Shiotani A, Mukobayashi $\mathrm{C}$, Oohata $\mathrm{H}$, Yamanishi $\mathrm{T}$, Hara $\mathrm{T}$, Itoh $\mathrm{H}$, et al. Wegener's granulomatosis with dural involvement as the initial clinical manifestation. Intern Med 1997:36:514-18.

6 Nishino H, Rubino FA, DeRemee RA, Swanson JW, Parisi JE. Neurological involvement in Wegener's granulomatosis: an analysis of 324 consecutive patients at the Mayo Clinic. Ann Neurol 1993;33:4-9.

7 Specks U, Moder KG, McDonald TJ. Meningeal involvement in Wegener granulomatosis. Mayo Clin Proc 2000;75:856-9
8 Spranger $M$, Schwab S, Meinck HM, Tischendorf M, Sis J, Breitbart A, et al. Meningeal involvement in Wegener's granulomatosis confirmed and monitored by positive circulating antineutrophil cytoplasm in and monitored by positive circulating antineutrop

Katrib A, Portek I, Corbett AJ, Hersch MI, Zagami AS. Meningeal involvement in Wegener's granulomatosis. J Rheumatol 1998;25:1009-1 1 . 10 Scarrow AM, Segal R, Medsger TA Jr, Wasko MC. Communicating hydrocephalus secondary to diffuse meningeal spread of Wegener's granulomatosis: case report and literature review. Neurosurgery 1998;43:1470-3.

\section{Extremely high dose pravastatin may suppress amyloidogenesis in a mouse model}

\section{S Shtrasburg, M Pras, M Lidar, A Livneh}

$\mathrm{P}$ ravastatin is a cholesterol lowering agent,' recently reported to have anti-inflammatory properties. ${ }^{2}$ It was suggested that the prevention and regression of atherosclerosis by pravastatin is partially related to its anti-inflammatory effect, ${ }^{2}$ probably mediated by inhibition of proinflammatory cytokines. ${ }^{3}$ Pravastatin's anti-inflammatory effect is associated with, and probably reflected by, reduced levels of the acute phase reactants, $C$ reactive protein and serum amyloid A (SAA). ${ }^{2}$ The $\mathrm{N}$-terminal fragment of the SAA is amyloid A (AA), which is deposited in a fibrillar form in the tissues of up to $30 \%$ of patients with a variety of chronic infectious and chronic inflammatory disorders, leading to reactive amyloidosis.

Because prevention and treatment of AA amyloidosis are currently unsatisfactory and reactive amyloidosis is a potentially lethal complication, it is important to find out whether pravastatin affects amyloidogenesis.

The effect of pravastatin on amyloidogenesis was studied in several groups of male Swiss mice 7-17 weeks old, which were subjected to amyloid induction, using intravenous amyloid enhancing factor ( $1 \mu \mathrm{g}$ in $0.5 \mathrm{ml}$ phosphate buffered saline on day 0 ) and subcutaneous $\mathrm{AgNO}_{3}(0.5 \mathrm{ml} 2 \%$ daily, on days 0,1 , and 2), according to our published protocol. ${ }^{5}$ Two groups of study mice (groups I and II) received intraperitoneal pravastatin $0.4 \mathrm{mg} /$ day in $0.5 \mathrm{ml}$ saline, and two other groups (III and IV) received intraperitoneal pravastatin $10 \mathrm{mg} /$ day. The human oral dose analogous to these regimens is $0.5 \mathrm{mg} / \mathrm{kg}$ and $12.5 \mathrm{mg} / \mathrm{kg}$ respectively (assuming a 20-fold increase in drug catabolism in mice as compared with man). The experiments lasted for 72 hours (groups I and III) or 96 hours (groups II and IV). The 72 hour interval, during which the amount of amyloid deposits is still low, allows the detection of a mild inhibition. All experiments were controlled by mice of the same strain, sex, and age, which received the same amyloid induction regimen, but $0.5 \mathrm{ml}$ saline intraperitoneally instead of pravastatin. The amount of amyloid deposition in the spleen was studied by the crush and smear technique and a five grade score, estimated by polarised microscopy. ${ }^{6}$ All experiments were repeated two to three times.

Amyloidosis in mice receiving pravastatin was somewhat less abundant and developed in fewer animals than in controls (table 1). This trend was noted only in animals receiving 10 $\mathrm{mg} /$ day and only in the short term experiments, but the statistical significance obtained was inconsistent (table 1). No amyloid inhibition by pravastatin was seen in any of the other experiments, either when a lower pravastatin dose $(0.4$ $\mathrm{mg} /$ day) was used or when mice were subjected to a longer (96 hours) amyloidogenic stimulus.

These findings suggest that pravastatin in a very high dose may have a mild amyloid protecting effect and thus increases

\begin{tabular}{|c|c|c|c|c|}
\hline $\begin{array}{l}\text { Group III* } \\
\text { experiment } \\
\text { number }\end{array}$ & $\begin{array}{l}\text { Type of } \\
\text { experiment }\end{array}$ & $\begin{array}{l}\text { Amyloid } \\
\text { positive mice } \\
\text { per group }\end{array}$ & $\begin{array}{l}\text { Median } \\
\text { (range) of } \\
\text { amyloid grade }\end{array}$ & $\stackrel{p}{\text { Values }}$ \\
\hline 1 & $\begin{array}{l}\text { Study } \\
\text { Control }\end{array}$ & $\begin{array}{l}5 / 6 \\
6 / 6\end{array}$ & $\begin{array}{l}2.5(0-3) \\
1.5(1-3)\end{array}$ & 0.24 \\
\hline 2 & $\begin{array}{l}\text { Study } \\
\text { Control }\end{array}$ & $\begin{array}{l}4 / 6 \\
6 / 6\end{array}$ & $\begin{array}{l}0.75(0-1.5) \\
2.0(0.5-3)\end{array}$ & 0.03 \\
\hline 3 & $\begin{array}{l}\text { Study } \\
\text { Control }\end{array}$ & $\begin{array}{l}2 / 5 \\
5 / 6\end{array}$ & $\begin{array}{l}0.5(0-3) \\
2.0(0-2.5)\end{array}$ & 0.07 \\
\hline Combined & $\begin{array}{l}\text { Study } \\
\text { Control }\end{array}$ & $\begin{array}{l}11 / 17 \\
17 / 18\end{array}$ & $\begin{array}{l}1.0(0-3) \\
2.0(0-3)\end{array}$ & 0.05 \\
\hline
\end{tabular}

*Amyloidosis was induced by amyloid enhancing factor and $\mathrm{AgNO}$ Study animals received intraperitoneally pravastatin $10 \mathrm{mg} /$ day on days 0,1 , and 2 . Control mice received $0.5 \mathrm{ml}$ saline instead. The mice were killed after 72 hours $(24$ hours after the last pravastatin injection) and the amount of splenic amyloid was estimated by the Crush and Smear technique; fusing Fisher's exact probability test.

the spectrum of drugs with a possible tangible amyloid preventive effect. Further studies are warranted to determine underlying mechanisms and to see whether other statins also have anti-amyloidogenic qualities.

\section{Authors' affiliations}

S Shtrasburg, M Pras, M Lidar, A Livneh, Heller Institute of Medical Research, Sheba Medical Centre, Tel-Hashomer, Israel

Correspondence to: Dr S Shtrasburg, Heller Institute of Medical Research, Sheba Medical Centre, Tel Hashomer 52621, Israel; shmuels@sheba.health.gov.il

Accepted 13 December 2001

\section{REFERENCES}

1 Keidar S, Aviram M, Maor I, Oiknine J, Brook JG. Pravastatin inhibits cellular cholesterol synthesis and increases low density lipoprotein receptor activity in macrophages: in vitro and in vivo studies. $\mathrm{Br} \mathrm{J}$ Clin Pharmacol 1994;38:513-19.

2 Ridker PM, Rifai N, Pfeffer MA, Sacks FM, Moye LA, Goldman S, et al. Inflammation, pravastatin and risk of coronary events after myocardial infarction in patients with average cholesterol levels. Circulation 1998;98:839-44.

3 Rosenson RS, Tangney CC, Casey LC. Inhibition of proinflammatory cytokine production by pravastatin. Lancet 1999;353:983-4.

4 Yakar S, Livneh A, Kaplan B, Pras M. The molecular basis of reactive amyloidosis. Semin Arthritis Rheum 1995;24:255-61.

5 Shtrasburg S, Livneh A, Gal R, Pras M. Extremely active murine amyloid enhancing factor. Clin Exp Rheumatol 1996;14:37-42.

6 Shtrasburg S, Gal R, Pras M. Crush and smear technique for rapid detection and semiquantitation of amyloid deposition. Biotech Histochem $1991 ; 66: 203-7$ 